\title{
HYDROLOGIC IMPACTS DUE TO THE CHANGES IN RIPARIAN BUFFER IN A HEADWATER WATERSHED
}

Keywords:

Headwater Watershed

Land Cover Scenarios

Atlantic Forest

DHSVM

Brazilian Forest Act

Histórico:

Recebido 23/07/2016

Aceito $14 / 03 / 2017$

Palavras chave: Bacia Hidrográfica de cabeceira Cenários de Cobertura do Solo Mata Atlântica DHSVM

Lei Florestal Brasileira

\section{${ }^{+}$Correspondência: livia.aalvarenga@deg.ufla.br}

DOI:

ABSTRACT: In recent years, concerns regarding the impacts of deforestation of riparian vegetation on water resources have created social and political tensions in Brazil. This research analyzed simulated hydrologic components of a $6.76 \mathrm{~km}^{2}$ headwater watershed with different widths of riparian vegetation. Lavrinha Watershed (LW) hydrological responses were simulated using the Distributed Hydrology Soil Vegetation Model (DHSVM), which was forced using meteorological data from one station (2005-20I0). Land cover scenarios where the percent land cover of Atlantic Forest was increased from the control resulted in changes in hydrologic components in the watershed due to increased evapotranspiration and rainfall interception and reduced runoff and overland flow. The base flow/runoff relationship has increased, suggesting that riparian vegetation plays an important role in groundwater recharge. Modeling of hydrologic components linked to riparian buffer scenarios, such as the process used in this study, can be a useful tool for decision-making strategies regarding watershed management.

\section{IMPACTOS HIDROLÓGICOS DEVIDO ÀS ALTERAÇÕES NA LARGURA RIPÁRIA EM UMA BACIA HIDROGRÁFICA DE CABECEIRA}

RESUMO: Nos últimos anos, as preocupações quanto aos impactos do desmatamento da vegetação ripária nos recursos hídricos criaram tensões sociais e políticas no Brasil. Esta pesquisa analisou os componentes hidrológicos simulados de uma bacia hidrográfica de cabeceira de $6,76 \mathrm{~km}^{2}$ com diferentes larguras de vegetação ripária. As respostas hidrológicas da Bacia Hidrográfica Lavrinha (BHL) foram simuladas utilizando o Distributed Hydrology Soil Vegetation Model (DHSVM) que foi forçado usando dados meteorológicos de uma estação (2005-2010). Os cenários de cobertura do solo em que o percentual da Mata Atlântica foi aumentado do controle resultaram em mudanças nas componentes hidrológicas na bacia hidrográfica devido ao incremento da evapotranspiração e intercepção da precipitação e redução do escoamento total e escoamento superficial. A relação escoamento base/escoamento total aumentou, sugerindo que a vegetação ripária desempenha um papel importante na recarga de água subterrânea. A modelagem dos componentes hidrológicos, associada aos cenários de larguras ripárias, como o processo utilizado para este estudo, pode ser uma ferramenta útil para as estratégias de tomada de decisão referente à gestão de bacias hidrográficas.

\footnotetext{
' Federal University of Lavras - Lavras, Minas Gerais, Brazil

${ }^{2}$ National Center for Natural Disaster Monitoring and Alerts - São José dos Campos, São Paulo, Brazil
} 


\section{INTRODUCTION}

Almost two-thirds of the Brazilian territory still has a prevalence of natural vegetation. Brazil is among the biologically richest nations in the world and contains substantial areas for biodiversity conservation (SPAROVEK et al., 2012). The Atlantic Forest occupies an area of $28,586 \mathrm{~km}^{2}$ in Minas Gerais state, which means $10.3 \%$ of the remnants of this land cover in Minas Gerais state (FSOSMA; INPE, 20I5). This ecosystem has been widely studied as it plays an important role in the water cycle, mainly through influencing rainfall interception, evapotranspiration, soil infiltration, and groundwater recharge. Thus, the hydrologic components in watersheds with Atlantic Forest land cover have been the object of many scientific studies at field level (ÁVILA et al., 20I4; RIBEIRO et al., 2009; SALEMI et al., 20I3).

Riparian forests have historically formed the natural interface between hill slope and aquatic processes for most watersheds worldwide (SWEENEY; NEWBOLD, 2014). Studies have shown that forested riparian zones are widely recognized for their importance in storing and fixing carbon, serving as wildlife habitats and ecological corridors, stabilizing stream banks and providing specific micro-climates, organic matter and food to the streams and their biota. The forested riparian zones also retain sediment and chemicals (fertilizers and pesticides) applied on the cultivated/agricultural sites on upslope regions of the watersheds (SALEMI et al., 20I2; ZHAO et al., 20I3).

According to the Atlas dos Remanescentes Florestais da Mata Atlântica, only approximately I2\% of the Brazilian Atlantic Forest remnants can be found until 20I4 (FSOSMA; INPE, 20I5). Agricultural and livestock are very strong economic activities in Brazil, in Middle-West states, towards Amazonia Forest, and over mountainous regions mainly in Southeast Brazil. Large areas have been deforested recently for expanding the above-mentioned activities, and many hydrological problems has occurred, such as, sediment transport towards to drainage network, low quality in the water and impact on water supplies, among others. In this context, the Brazilian Government created a set of laws aiming to reduce these impacts and guarantee the sustainability of ecological and water resources. These set of laws are marked by the creation of buffers along the water courses, whose primary function is protecting the biota and water resources against sediment transport and chemicals, and by favoring the water infiltration and reduction of overland flow. Sweeney and Newbold (2014) also emphasized in an analysis of water quality, habitat, and biota protection in small streams that, overall, a forest buffer greater than or equal to $30 \mathrm{~m}$ is needed to protect the physical, chemical, and biological integrity of small streams. In Brazil, Permanent Preservation Areas (PPAs) or riparian buffer areas are used to protect water resources, soil and biodiversity and serve as green corridors in the landscape (SPAROVEK et al., 2012). Thus, a detailed overview of PPA widths, established for the purpose of environmental conservation, can be found in the Brazilian Forest Act I 265 I/20 I 2 (BRASIL, 20 I2).

The use of distributed hydrological models is necessary in order to provide a detailed distributed view of the relationships among hydrology, vegetation, soil and climate in a watershed (CUARTAS et al., 20I2). The Distributed Hydrology Soil Vegetation Model (DHSVM) is a spatially distributed, physically based hydrological model developed for mountainous watersheds. DHSVM is often applied to simulate the effects of land cover changes on hydrologic components such as soil moisture, ground water level, evapotranspiration, and streamflow (ALVARENGA et al., 2016; CHU et al., 20 I0; CUO et al., 2009; THANAPAKPAWIN et al., 2007).

Riparian buffer areas are especially important along the rivers of the headwater watersheds as these hydrological units are suffering with deforestation in Southeast Brazil, highlighting Mantiqueira Range, which is one of the most important Brazilian headwater regions from a water yield point of view. Other studies were developed in this region, showing the role of the native forest to maintain the streamflow, evaluating the impacts of different scenarios of land-use and climate change over the hydrology of the region (MENEZES et al., 2009; CAMPOS et al., 20I5; ALVARENGA et al., 20I6a, ALVARENGA et al., 20l6b). However, these authors did not show the importance of buffer areas for the entire watershed, taking the current riparian areas as reference. Thus, the main purpose of this study is to simulate how the buffer areas can influence the hydrology of a headwater watershed following that which is preconized by the Brazilian Forest Act. Within this context, the DHSVM was used for analyzing the effects of different riparian buffer scenarios on the hydrologic components, as this model was designed focusing in the hydrology of mountainous regions, being more sensitive to vegetation changes than other models, however, little applied in Brazil.

\section{MATERIAL AND METHODS}

\section{Study site description}

The entire watershed grid contained 7516 (30 x $30 \mathrm{~m}$ ) grid cells, an area of about $6.76 \mathrm{~km}^{2}$, which agrees 
with published values of the Lavrinha watershed (LW) area (MENEZES et al., 20l4). The LW, with elevations between 1137 and $1733 \mathrm{~m}$ (digital elevation modelDEM with $30 \mathrm{~m}$ resolution), is located in the Grande River Basin, in the Mantiqueira Range, which is the most important headwater region of Southeastern Brazil (Figure I). The Mantiqueira Range region holds several headwaters that form important rivers in southern Minas Gerais state. Its southern region is important for public water supply, irrigation and hydropower (PINTO et al., 2013; VIOLA et al., 2014).

The climate of the region is classified as Cwa, according to Köppen classification method, i.e., with rainy summers and dry winters. The water year for the region is defined as the period between October of a given year and September of the following year. Observed rainfall was $2054,2395,2515$, and $2134 \mathrm{~mm}$ for water years $2006 / 2007,2007 / 2008,2008 / 2009$, and 2009/2010 respectively. The rainy season in the Mantiqueira Range is from October to March, and the average annual temperature is $17^{\circ} \mathrm{C}$. In this region, storms with duration of longer than one day occur in the summer and are controlled by large scale synoptic weather systems, such as, cold fronts and the South Atlantic Convergence Zone (LIMA et al., 20I0).

\section{Model description and inputs}

The Distributed Hydrology Soil Vegetation Model (DHSVM) version 3.1.2 was used in this study to simulate the hydrology of the LW. The DHSVM is a spatially distributed, physically explicit hydrological model, developed in the 1990s at the University of Washington, for mountainous regions (WIGMOSTA et al., 1994). The DEM provides the topographic controls of the incoming shortwave radiation, precipitation, air temperature, and downslope water movement (WIGMOSTA et al., 2002; WIGMOSTA et al., 1994). The model combines modules, such as: two-layer canopy representation for evapotranspiration; percolation in unsaturated moisture zone is calculated using Darcy's law with the BrooksCorey equation used to calculate hydraulic conductivity; saturated subsurface flow exists in the deepest soil layer profile; in locations where the water table of a grid cell intersects the ground surface is generated surface overland flow; stream segment storage and propagation are computed using linear-reservoir routing. It explicitly solves the mass and energy balance equations for each grid cell of the digital elevation model (DEM) for every time step.

The Geographical Information System (GIS) ARC/ INFO was used to process all necessary maps. The model was run using a DEM at a 30 meter resolution. The DEM was obtained from a contour line map at a 1:50000 scale, and points of known altitude (Instituto Brasileiro de Geografia e Estatística - IBGE, 1973). All sinks were filled in the DEM. Thus, the DEM was used to delineate the LW, and the soil depth grid and the stream network were generated using an Arc Macro Language process based on the $30 \mathrm{~m}$ DEM. The soil depth values are calculated using an algorithm that estimates it based on slope, upstream contributing area and elevation, and for Lavrinha Watershed, these values are between 2.5 and $5.0 \mathrm{~m}$ (ALVARENGA et al., 2016a). These estimations were validated based on Oliveira et al. (2014) who conducted a fortnightly monitoring of water table depth in a small catchment within the LW area.

The soil map was adapted from an existing soil survey, and the soil types are Haplic Cambisol ( $92 \%$ of the area), Haplic Gleisol (I\% of the area), and Fluvic Neosol (7\% of the area) (MENEZES et al., 2009). The Haplic Cambisol presents shallow soil with low infiltration and high erodibility. The Fluvic Neosol and Haplic Gleisol are located close to the drainage network, presenting a deeper soil layer than the Haplic Cambissol. In general, the soils are relatively shallow and have limited water-

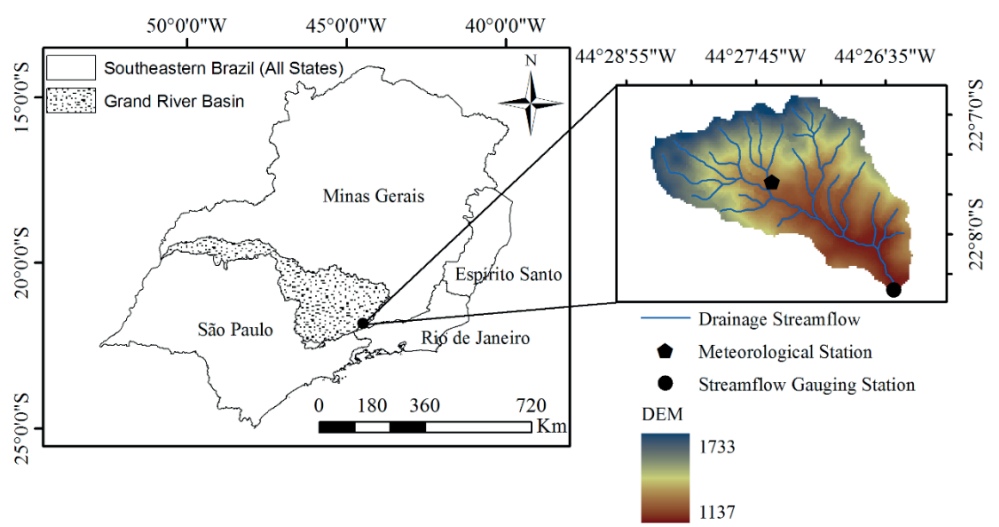

FIGURE I Geographical location of the LW in Mantiqueira Range region, southeastern Brazil; and DEM (with meteorological station and streamflow gauging station). 
holding capacity, which means the importance of the buffer areas for protection the drainage network and water bodies, as under these soils, the negative impacts are generally more intensified as presented and discussed by Pinto et al. (2015) who studied the role of the Inceptisols (Cambisols) on the hydrology of this watershed.

Each grid cell at a 30 meter resolution in the LW is assigned various characteristics such as, soil and vegetation types, elevation and slope. Many data and parameters are required to successfully simulate hydrologic components with DHSVM. All soil and vegetation parameters were based on literature. Vegetation parameters were not changed in the calibration. There are three types of soils and based on the sensitivity analysis of DHSVM, lateral and vertical soil hydraulic conductivity and exponential decrease rate of lateral soil hydraulic conductivity were used to calibrate the model (ALVARENGA et al., 20l6a). The model requires a time-series of meteorological data as inputs (precipitation, temperature, wind speed, relative humidity, shortwave, and longwave solar radiation). In this study, hourly meteorological data were used for simulations. Simulations were performed using one-hour time steps.

\section{Riparian buffer scenarios}

Six different land cover scenarios were used to evaluate how increases in riparian buffer areas might affect watershed hydrology. The control land cover was generated based on a 10 meter resolution ALOS (Advanced Land Observing Satellite) image from 2008, using a supervised classification through the maximum likelihood classifier. All land cover layers were created in ArcGIS for each 30 meter grid cell (Figure 2).

In order to evaluate the effects of riparian buffer scenarios on hydrologic components, the coverage scenarios of riparian vegetation were constructed based on current land-use (Figure 2 (a)) and on the Brazilian Forest Act (FA) considering thresholds of Permanent Preservation Areas (PPAs) along the water body (Brazilian Forest Act I265 I/20I2) (BRASIL, 20I2). According to Sparovek et al. (20I2), the FA is the most important legal framework in Brazil for regulating conservation and restoration on private land, covering all natural vegetation.

The riparian buffer scenarios along drainage network were $30 \mathrm{~m}$ (Figure 2 (b)), $50 \mathrm{~m}$ (Figure 2 (c)), $100 \mathrm{~m}$ (Figure 2 (d)), $200 \mathrm{~m}$ (Figure 2 (e)), and the entire area covered by Atlantic Forest (Figure 2 (f)) which correspond with the PPA thresholds from the Brazilian Forest Act. From the control scenario (current land- use, Figure $2(a))$, in each riparian buffer scenario was created Atlantic forest instead pasture along the drainage network, based on Brazilian Forest Act. Importantly, the Brazilian Forest Act prescribes that the APPs should have a $30 \mathrm{~m}$ width along a river bank whose width is less than $10 \mathrm{~m}$. The percentages of land cover changes of each scenario are presented in Figure 2.
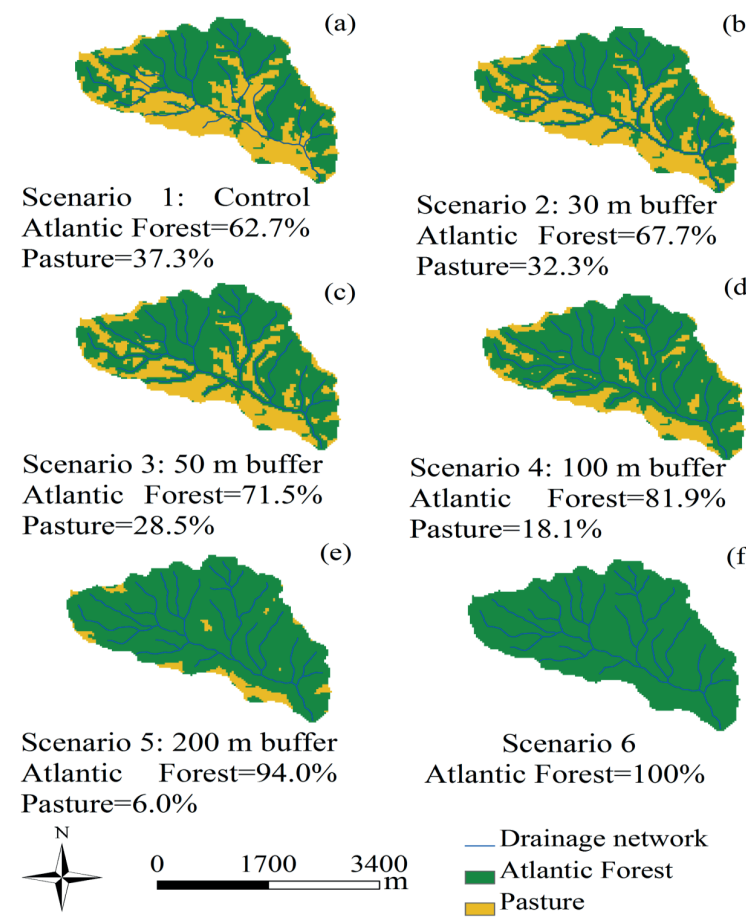

Scenario 2: $30 \mathrm{~m}$ buffer Atlantic Forest $=67.7 \%$ Pasture $=32.3 \%$

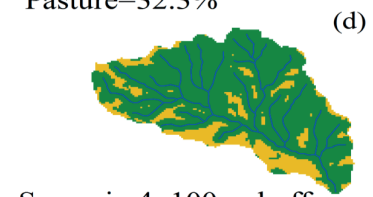

Scenario 4: $100 \mathrm{~m}$ buffer Atlantic Forest $=81.9 \%$ Pasture $=18.1 \%$

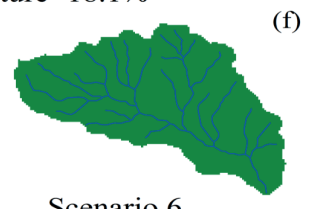

Scenario 6

Atlantic Forest $=100 \%$

$$
\begin{aligned}
& \text { _Drainage network } \\
& \text { Atlantic Forest } \\
& \square \text { Pasture }
\end{aligned}
$$

FIGURE 2 Scenarios of riparian buffer (Atlantic Forest) for the LW to evaluate hydrologic components through DHSVM.

\section{Model calibration and validation}

Meteorological station data sets (Figure I) from 2005 to 2010 were used for the initialization, calibration, and validation of the model. These data sets were previously used by Alvarenga et al. (2016a), Alvarenga et al. (2016b) and Pinto et al. (2015), who evaluated the consistence, existence of gaps on the series and spatial behavior of the precipitation, based on another meteorological station and pluviometer, both installed in other parts of the watershed. According to Alvarenga et al. (20l6a), these data sets have demonstrated good quality to explain the water budget on the watershed, allowing us to conclude that they have a second level of hydrological consistence. To obtain the observed streamflow during the calibration and validation periods, an automatic water level gauge was used, equipped with a pressure sensor (observed data) (Figure I) at the LW outlet, whose quality was also controlled by means a good fit of the stage-discharge rating curve and 
water balance simulation (Alvarenga et al., 2016a). The period from January 2005 to September 2006 was used to warm up the model. The calibration process was carried out taking into account the period from October I, 2006 to September 30, 2008; and for validation, the period from October I, 2008 to September 30, 2010.

The Nash-Sutcliffe efficiency (E) was used to evaluate DHSVM performance in a simulated average daily and monthly streamflows. According to Safeeq and Fares (20I2), a value of $E$ more than 0.35 and less than 0.50 is considered an indicator of average performance; a value between 0.50 and 0.70 indicates good performance; and a value greater than 0.70 indicates very good performance.

DHSVM was applied to simulations of hydrologic components resulting from six land cover scenarios. Simulations with each riparian buffer scenarios (Scenarios 2, 3, 4, 5, and 6) were compared with simulation of current land-use in the LW (Scenario I) (Figure 2). The model outputs evaluated were evapotranspiration, rainfall interception, runoff, overland flow, and base flow, from October, 2006 to September, 2010.

\section{RESULTS AND DISCUSSION}

\section{DHSVM parameterization and perfomance}

DHSVM calibration was done through the determination of parameters to which streamflow was found to be most sensitive, in this case, the vertical and lateral saturated hydraulic conductivity and exponential decrease rate of lateral saturated hydraulic conductivity, as discussed in Alvarenga et al. (20l6a). To maximize the model efficiency $(E), 200$ simulations were performed with modifications to the sensitive parameters in order to calibrate the DHSVM.

The final soil and vegetation parameters used for this study were based on literature from Ávila (20II), Ávila et al. (20I4), Cuartas et al. (20I2), Junqueira Junior (2006), Kruk (2008), Oliveira (20I I), and Wigmosta et al. (1994). More details about the soil and vegetation parameters as well as the final hydrograph (observed and simulated streamflow) can be found in Alvarenga et al. (2016a). Final calibrated DHSVM soil parameters are summarized in Table I.

During calibration and validation phases, the daily and monthly simulated streamflow presented reasonable agreed with the observed streamflow. The model overall $E$ values for simulating daily average streamflow were 0.52 . Calibration and validation of the monthly
TABLE I Final calibrated DHSVM soil parameters values.

\begin{tabular}{cccc}
\hline \multirow{2}{*}{ Parameters } & \multicolumn{3}{c}{ Soil type } \\
\cline { 2 - 4 } & $\begin{array}{c}\text { Haplic } \\
\text { Cambisol }\end{array}$ & $\begin{array}{c}\text { Haplic } \\
\text { Gleisol }\end{array}$ & $\begin{array}{c}\text { Fluvic } \\
\text { Neosol }\end{array}$ \\
\hline $\begin{array}{c}\text { Lateral soil hydraulic } \\
\text { conductivity }\left(\mathrm{m} \cdot \mathrm{s}^{-1}\right)\end{array}$ & 0.000019 & 0.000028 & 0.000033 \\
$\begin{array}{c}\text { Exponential decrease rate of } \\
\text { lateral soil hydraulic conductivity }\end{array}$ & 0.005 & 0.300 & 0.010 \\
Vertical soil hydraulic conductivity & 0.0000190 & 0.0000280 & 0.0000330 \\
in each soil layer $\left(\mathrm{m} \cdot \mathrm{s}^{-1}\right)$ & 0.0000180 & 0.0000275 & 0.0000320 \\
\hline & 0.0000170 & 0.0000270 & 0.0000310 \\
\hline
\end{tabular}

average streamflow presented $E$ values of 0.63 and 0.77 , respectively (ALVARENGA et al., 2016a). These $E$ values are within published ranges using the DHSVM, - 2.22 to 0.79 (THANAPAKPAWIN et al., 2007) and -0.10 to 0.92 (CUO et al., 2009). Therefore, taking into account the classification proposed by Safeeq and Fares (2012), model performance is considered acceptable.

\section{Hydrological response}

The analysis of monthly hydrologic components from model simulations for the control scenario (Figure 3 (a) and (b)), shows that the effects on water balance of simulated runoff are more pronounced between October and March, when the watershed receives the majority of the rainfall (average $=317.5 \mathrm{~mm} /$ month). Runoff, overland flow and base flow showed similar peaks during the entire period studied (Figure 3 (a)). These results agree with those of Thanapakpawin et al. (2007) which indicate that excess overland flow saturation could be an important mechanism for runoff production when the simulation results is sensitive to soil lateral conductivity.

Figure 3 (b) shows the monthly rainfall interception by vegetation and evapotranspiration. Both hydrological elements are important to water balance if the land-use is changed for forest instead of pasture. The rainfall interception that accompanies the temporal rainfall pattern shows monthly maximum values in December, January, and February (values between 96 to $230 \mathrm{~mm} / \mathrm{month}$ and 161 to $633 \mathrm{~mm} /$ month for rainfall interception and rainfall, respectively). The highest evapotranspiration occurs between October and March and lessens from April to September. Subsequently, evapotranspiration tends to increase with increasing rainfall and air temperature in the LW.

\section{Riparian buffer change effects}

Analysis of simulation results for riparian vegetation changes show that evapotranspiration and rainfall interception both change with increases in riparian 


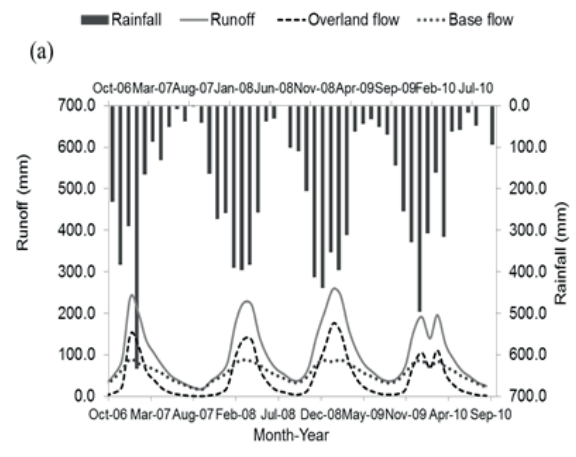

(b) Rainfall —Rainfall interception ---.Evapotranspiration

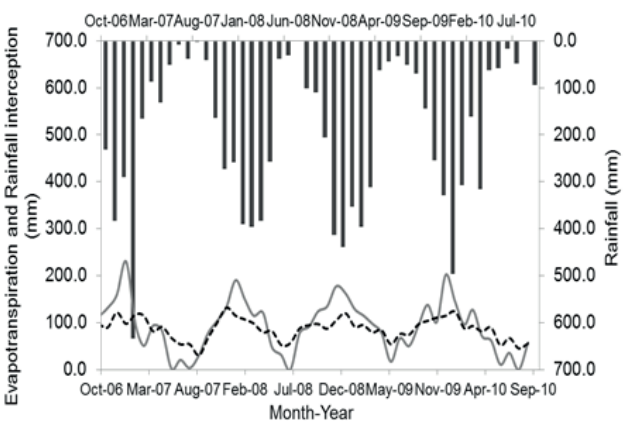

FIGURE 3 Monthly hydrologic components simulated by the DSHVM in LW for the control scenario.

vegetation from the control. Scenario 6 has a dominant effect on the increase of the total and daily average evapotranspiration and rainfall interception (Table 2). In mountainous regions, where overland flow occurs more easily, the impact of vegetation cover changes tends to be lower. However, there was a decrease in total and daily average of the overland flow and runoff with the riparian vegetation increase (Table 2 ).

Table 2 also indicates that these is a positive relationship between base flow/runoff and increases in riparian vegetation. We hypothesize that preferential pathways in riparian vegetation areas could be one of the main reasons for this $2.5 \%$ increase in the fraction of runoff converted into base flow. The overland flows have presented slightly decreasing trend as the buffer areas increase, varying from $44.4 \%$ (scenario $I$ and 2 ) to $41.9 \%$ (scenario 6). Therefore, these results suggest that the riparian vegetation is associated with higher infiltration capacity, groundwater recharge via vertical percolation and less overland flow, leading to greater base flow and less erosion and sediment flows into the drainage network of the watershed.

Groundwater storage (base flow) plays an important role in maintaining streamflow and evapotranspiration, as noted by Salemi et al. (2012, 2013). Moreover rainfall interception in forests is greater than in pasture, thus direct evaporation of intercepted rainfall tends to be higher in the Atlantic Forest. Therefore, the riparian forest has a dominant effect on evapotranspiration and all the analyzed water balance components are affected with an increase in evapotranspiration in the LW that showed mostly Atlantic Forest land cover in all scenarios. In agreement with Thanapakpawin et al. (2007), the watershed hydrology is sensitive to land cover changes, with a general pattern of decreased runoff with migration from crops to trees due to increasing evapotranspiration.

On the other hand, Chu et al. (2010) assessed the spatial and dynamic coherence of land use functions when exploring a watershed's potential, and their results highlighted that spatial land use changes, especially simultaneous changes involving deforestation, increased runoff and reduced infiltration, which are highly dependent on the spatial distribution of land use in the watershed. According to Viola et al. (2014), the deforestation of $30 \%$ and $70 \%$ of the forest remnants in the Mantiqueira Range region for the cultivation of grasslands could increase runoff by $57.63 \mathrm{~mm} \cdot$ year $^{-1}$ and $156.78 \mathrm{~mm} \cdot y^{-1}{ }^{-1}$, respectively, mostly due to the increase in overland flow. This indicates that landuse changes might make the watershed more prone to flooding and other hazards associated with increased runoff due to the reduction of evapotranspiration and rainfall interception.

Finally, from a water supply point of view, the effect of water conservation provided by the forest ecosystem has been well documented. Because of the soil properties under forest influence, such as litter and soil organic matter, it is possible to assert there will be higher soil porosity and more water infiltration into the soil, thereby reducing surface runoff, erosion, and flash responses to storm rainfall. Thus, the maintenance of riparian areas is fundamental for an environmental balance as it led to greater baseflow/runoff ratio (Table 2 ), which is highlighted desirable, and indeed, improves water quality (PINTO et al., 20 I3; NEARY et al., 2009).

\section{CONCLUSIONS}

At both daily and monthly time steps, the DHSVM was able to simulate hydrologic processes in the LW with acceptable performance, which is fundamental for the success of the study. The model is sensitive to changes in vegetation, as it was designed for similar purposes of this study, thus, it was possible to detect the impacts in the hydrological elements at the watershed scale from riparian buffer changes. However, the results obtained here via DHSVM simulation could be more accurate if a greater accurate DEM was used, like 5 or 10 m resolution, which for now is very difficult due to the costs involved. 
TABLE 2 Riparian buffers and the hydrologic components in each scenario throughout the studied period (total values ( $\mathrm{mm}$ ) and daily average values $\left(\mathrm{mm} \cdot\right.$ day $\left.\left.^{-1}\right)\right)$.

\begin{tabular}{|c|c|c|c|c|c|}
\hline Scenarios & $\begin{array}{l}\text { Evapotranspiration } \\
(\mathrm{mm})\end{array}$ & $\begin{array}{l}\text { Rainfall interception } \\
(\mathrm{mm})\end{array}$ & $\begin{array}{c}\text { Runoff } \\
\text { (mm) }\end{array}$ & $\begin{array}{l}\text { Overland flow } \\
(\mathrm{mm})\end{array}$ & $\begin{array}{c}\text { Base flow/Runoff } \\
(\%)\end{array}$ \\
\hline Scenario I & 4182.9 & 4453.2 & 4901.8 & 2175.5 & 55.6 \\
\hline $\begin{array}{l}\text { Average } \\
\left(\mathrm{mm} \cdot \text { day }^{\prime}\right)\end{array}$ & 2.9 & 3.0 & 3.4 & 1.5 & \\
\hline Scenario 2 & $\begin{array}{c}4265.8 \\
(+2.0 \%)\end{array}$ & $\begin{array}{c}4550.6 \\
(+2.2 \%)\end{array}$ & $\begin{array}{l}4819.4 \\
(-1.7 \%)\end{array}$ & $\begin{array}{l}2138.4 \\
(-1.7 \%)\end{array}$ & 55.6 \\
\hline $\begin{array}{c}\text { Average } \\
\left(\mathrm{mm} \cdot \text { day }^{-1}\right)\end{array}$ & 2.9 & $\begin{array}{c}3.1 \\
(+3.3 \%)\end{array}$ & $\begin{array}{c}3.3 \\
(-2.9 \%)\end{array}$ & 1.5 & \\
\hline Scenario 3 & $\begin{array}{c}4330.7 \\
(+3.5 \%)\end{array}$ & $\begin{array}{c}4632.6 \\
(+4.0 \%)\end{array}$ & $\begin{array}{l}4755.0 \\
(-3.0 \%)\end{array}$ & $\begin{array}{l}2106.3 \\
(-3.2 \%)\end{array}$ & 55.7 \\
\hline $\begin{array}{l}\text { Average } \\
\left(\mathrm{mm} \cdot \text { day }^{\prime}\right)\end{array}$ & $\begin{array}{c}3.0 \\
(+3.4)\end{array}$ & $\begin{array}{c}3.2 \\
(+6.7 \%)\end{array}$ & $\begin{array}{c}3.3 \\
(-2.9 \%)\end{array}$ & $\begin{array}{c}1.4 \\
(-6.7 \%)\end{array}$ & \\
\hline Scenario 4 & $\begin{array}{c}4504.6 \\
(+7.7 \%)\end{array}$ & $\begin{array}{c}4905.7 \\
(+10.2 \%)\end{array}$ & $\begin{array}{l}4584.6 \\
(-6.5 \%)\end{array}$ & $\begin{array}{l}2006.4 \\
(-7.8 \%)\end{array}$ & 56.2 \\
\hline Average & 3.1 & 3.4 & 3.1 & 1.4 & \\
\hline$\left(\mathrm{mm} \cdot \mathrm{day}^{-1}\right)$ & $(+6.9 \%)$ & $(+13.3 \%)$ & $(-8.8 \%)$ & $(-6.7 \%)$ & \\
\hline Scenario 5 & $\begin{array}{c}4706.5 \\
(+12.5 \%)\end{array}$ & $\begin{array}{l}5447.2 \\
(+22.3)\end{array}$ & $\begin{array}{c}4386.9 \\
(-10.5 \%)\end{array}$ & $\begin{array}{c}1866.5 \\
(-\mid 4.2 \%)\end{array}$ & 57.5 \\
\hline $\begin{array}{l}\text { Average } \\
\left(\mathrm{mm} \cdot \text { day }^{-1}\right)\end{array}$ & $\begin{array}{c}3.2 \\
(+10.3 \%)\end{array}$ & $\begin{array}{c}3.7 \\
(+23.3 \%)\end{array}$ & $\begin{array}{c}3.0 \\
(-11.8 \%)\end{array}$ & $\begin{array}{c}1.3 \\
(-13.3 \%)\end{array}$ & \\
\hline Scenario 6 & $\begin{array}{c}4804.7 \\
(+\mid 4.9 \%)\end{array}$ & $\begin{array}{c}5701.1 \\
(+28.0 \%)\end{array}$ & $\begin{array}{c}4289.5 \\
(-12.5 \%)\end{array}$ & $\begin{array}{c}1797.0 \\
(-17.4 \%)\end{array}$ & 58.1 \\
\hline $\begin{array}{l}\text { Average } \\
\left(\mathrm{mm} \cdot \text { day }^{-1}\right)\end{array}$ & $\begin{array}{c}3.3 \\
(+13.8 \%) \\
\end{array}$ & $\begin{array}{c}3.9 \\
(+30.0 \%)\end{array}$ & $\begin{array}{c}2.9 \\
(-14.7 \%)\end{array}$ & $\begin{array}{c}1.2 \\
(-20.0 \%)\end{array}$ & \\
\hline
\end{tabular}

Land cover changes with an increase in the riparian buffer of Atlantic Forest $(30 \mathrm{~m}$ width up to the entire area covered by Atlantic Forest) showed changes in the hydrologic components, such as an increase in evapotranspiration (2.0 to $14.9 \%$ ) and rainfall interception (2.2 to $28.0 \%$ ), and a decrease in overland flow (1.7 to 12.4\%). There was an increase of $2.5 \%$ in the base flow/runoff ratio, which means that the watershed hydrological responses to riparian vegetation recover following the Brazilian Forest Act was positive. The dynamics of the hydrologic components, in relation to the riparian vegetation increase, can be applied as a useful supporting tool for watershed management mainly in headwater regions with Atlantic Forest as land-use, for which exist only a few related studies. Research data and measurements of the effect on water balance under riparian buffer changes are lacking in Brazil. Therefore, the results obtained here can support not only the watershed management and ecological services in mountainous regions, but also to be used as backgrounds to upgrade the Brazilian Forest Act in the future.

\section{REFERENCES}

ALVARENGA, L. A.; MELLO, C. R.; COLOMBO, A.; CUARTAS, L. A.; BOWLING, L. C. Assessment of land cover change on the hydrology of a Brazilian headwater watershed using the Distributed Hydrology-Soil-Vegetation Model. CATENA, v. 143, p. 7-17, 2016 a.
AlVARENGA, L. A.; MELlO, C. R.; COlOMBO, A.; CUARTAS, L. A.; CHOU, S. C. Hydrological responses to climate changes in a headwater watershed. Ciência e Agrotecnologia, v. 40, n. 6, p. 647-657, 2016 b.

ÁVILA, L. F. Balanço hídrico em um remanescente de Mata Atlântica da Serra da Mantiqueira, MG. 201 I. I78 p. PhD thesis. Universidade Federal de Lavras, Lavras.

ÁVILA, L. F; MELLO, C. R.; PINTO, L. C.; SILVA, A. M. Partição da precipitação pluvial em uma microbacia hidrográfica ocupada por Mata Atlântica na Serra da Mantiqueira, MG. Ciência Florestal, v. 24, n. 3, p. 583-595, 2014.

BRASIL. Lei $n^{\circ} 1265$ I, de 25 de maio de 20I2. Dispõe sobre a proteção da vegetação nativa. Brasília, 20I2. Available at: <http://www.jusbrasil.com.br/legislacao// 032082/lei|265|-|2>. Accessed in: 9 November 2014.

CHU, H. J.; LIN, Y. P.; HUANG, C. W.; HSU, C. Y.; CHEN, $H$. Y. Modelling the hydrologic effects of dynamic land-use change using a distributed hydrologic model and a spatial land-use allocation model. Hydrological Processes, v. 24, n. I8, p. 2538-2554, 2010.

CUARTAS, L. A.; TOMASELLA, J.; NOBRE, A. D.; NOBRE, C. A.; HODNETT, M. G.; WATERLOO, M. J.; OLIVEIRA, S. M.; VON RANDOW, L.A.; TRANCOSO, R.; FERREIRA, $M$. Distributed hydrological modeling of a micro-scale rainforest watershed in Amazonia: model evaluation and advances in calibration using the new HAND terrain model. Journal of Hydrology, v. 462, p. 15-27, 2012. 
CUO, L.; LETTENMAIER, D. P.; ALBERTI, M.; RICHEY, J. E. Effects of a century of land cover and climate change on the hydrology of the Puget Sound basin. Hydrological Processes, v. 23, n. 6, p. 907-933, 2009.

FUNDAÇÃO S.O.S. MATA ATLÂNTICA (FSOSMA); INSTITUTO NACIONAL DE PESQUISAS ESPACIAIS (INPE). Atlas dos remanescentes florestais da Mata Atlântica: período 2013-20I4. São Paulo, 20I5. 60 p.

INSTITUTO BRASILEIRO DE GEOGRAFIA E ESTATÍ́sTICA. Carta do Brasil. Rio de Janeiro, 1973. I mapa. Escala: I:50000.

JUNQUEIRA JÚNIOR, J. A. Escoamento de nascentes associado à variabilidade espacial de atributos físicos e uso do solo em uma bacia hidrográfica de cabeceira do Rio Grande, MG. 2006. 84 p. Dissertation. Universidade Federal de Lavras, Lavras.

KRUK, N. S. Sistema hidrometeorológico proposto para previsão de eventos extremos numa microbacia de topografia complexa. 2008. I89 p. PhD thesis. Instituto Tecnológico de Aeronáutica, São José dos Campos.

LIMA, K. C.; SATYAMURTY, P.; FERNÁNDEZ, J. P. R. Largescale atmospheric conditions associated with heavy rainfall episodes in Southeast Brazil. Theoretical and Applied Climatology, v. I0I, n. I/2, p. I2I-135, 2010.

MENEZES, M. D.; JUNQUEIRA JÚNIOR, J. A.; MELLO, C. R.; SILVA, A. M.; CURI, N.; MARQUES, J. J. Dinâmica hidrológica de duas nascentes, associada ao uso do solo, características pedológicas e atributos físico-hídricos na sub-bacia hidrográfica do Ribeirão Lavrinha-Serra da Mantiqueira (MG). Scientia Forestalis, v. 37, n. 82, p. I75-I84, 2009.

MENEZES, M. D. D.; SILVA, S. H. G.; MELLO, C. R.; OWENS, P. R.; CURI, N. Solum depth spatial prediction comparing conventional with knowledge-based digital soil mapping approaches. Scientia Agricola, v. 7I, n. 4, p. 316-323, 20 I4.

NEARY, D. G.; ICE, G. G.; JACKSON, C. R. Linkages between forest soils and water quality and quantity. Forest Ecology and Management, v. 258, n. I0, p. 2269-228I, 2009.

OLIVEIRA, A. S. de. Dinâmica do escoamento em nascentes na região do Alto Rio Grande, MG. 20। I. 130 p. Dissertation. Universidade Federal de Lavras, Lavras.

OLIVEIRA, A. S. D.; SILVA, A. M. D.; MELLO, C. R.; ALVES, G. J. Stream flow regime of springs in the Mantiqueira Mountain Range region, Minas Gerais State. Cerne, v. 20, n. 3, p. 343-349, 2014.

PINTO, L. C.; MELLO, C. R.; ÁVILA, L. F. Water quality indicators in the Mantiqueira Range region, Minas Gerais state. Cerne, v. 19, n. 4, p. 687-692, 2013.
PINTO, L. C.; MELLO, C. R.; OWENS, P. R.; NORTON, L. D.; CURI, N. Role of inceptisols in the hydrology of mountainous catchments in Southeastern Brazil. Journal of Hydrologic Engineering, v. 2I, n. 2, p. 050I50I7, 2015.

RIBEIRO, M. C.; METZGER, J. P.; MARTENSEN, A. C.; PONZONI, F. J.; HIROTA, M. M. The Brazilian Atlantic Forest: how much is left, and how is the remaining forest distributed? Implications for conservation. Biological Conservation, v. I42, n. 6, p. I|4 I-I I53, 2009.

SAFEEQ, M.; FARES, A. Hydrologic response of a Hawaiian watershed to future climate change scenarios. Hydrological processes, v. 26, n. 18, p. 2745-2764, 2012.

SALEMI, L. F.; GROPPO, J. D.; TREVISAN, R.; MORAES, J. M.; BARROS FERRAZ, S. F; VILLANI, J. P.; DUARTE-NETO, P. J.; MARTINELLI, L. A. Land-use change in the Atlantic rainforest region: consequences for the hydrology of small catchments. Journal of Hydrology, v. 499, p. I00-109, 2013.

SALEMI, L. F.; GROPPO, J. D.; TREVISAN, R.; DE MORAES, J. M.; PAULA LIMA, W.; MARTINELLI, L. A. Riparian vegetation and water yield: a synthesis. Journal of Hydrology, v. 454, p. 195-202, 2012.

SPAROVEK, G.; BERNDES, G.; BARRETTO, A. G. D. O. P.; KLUG, I. L. F. The revision of the Brazilian Forest Act: increased deforestation or a historic step towards balancing agricultural development and nature conservation? Environmental Science \& Policy, v. 16, p. $65-72,2012$.

SWEENEY, B. W.; NEWBOLD, J. D. Streamside forest buffer width needed to protect stream water quality, habitat, and organisms: a literature review. Journal of the American Water Resources Association, v. 50, n. 3, p. $560-584,2014$.

THANAPAKPAWIN, P.; RICHEY, J.; THOMAS, D.; RODDA, S.; CAMPBELL, B.; LOGSDON, M. Effects of landuse change on the hydrologic regime of the Mae Chaem river basin, NW Thailand. Journal of Hydrology, v. 334, n. I, p. 2I 5-230, 2007.

VIOLA, M. R.; MELLO, C. R.; BESKOW, S.; NORTON, L. $D$. Impacts of land-use changes on the hydrology of the grande river basin headwaters, southeastern Brazil. Water Resources Management, v. 28, n. 13, p. 4537-4550, 2014.

WIGMOSTA, M. S.; NIJSSEN, B.; STORCK, P. The distributed hydrology soil vegetation model. In: SINGH, V. P.; FREVERT, D. K. (Ed.). Mathematical models of small watershed hydrology and applications. Colorado: Water Resources, p. 7-42, 2002.

WIGMOSTA, M. S.; VAIL, L. W.; LETTENMAIER, D. P.A distributed hydrology-vegetation model for complex terrain. Water Resources Research, v. 30, n. 6, p. I665-1679, 1994.

ZHAO, P.; XIA, B.; HU, Y.; YANG, Y. A spatial multi-criteria planning scheme for evaluating riparian buffer restoration priorities. Ecological Engineering, v. 54, p. 155-164, 2013. 